\title{
PENGGUNAAN MODEL PEMBELAJARAN INTERAKTIF PADA MATERI TUMBUHAN
}

\author{
Rini Nafsiati Astuti \\ Dosen pada program studi PGMI
}

\begin{abstract}
This article tries to discuss about the using of interactive teaching model to help students to understand and develop plant concept in their daily lives. Interactive teaching model is a teaching model that focuses on students' questions aspect. Interactive teaching model of the plant concept is based on constructivist approach contain characteristic of science teaching. Teaching characteristic of plant concept is by pay attention and consider the students' early knowledge which can be gained from the environment outside the school.

Teacher can help find out the students' knowledge as early understanding about plant concept and also give the opportunity for students to construct their knowledge. The steps to apply the interactive teaching model are preparation, before views, exploratory activities, students' question, investigations, after views and reflections. The use of interactive teaching model can help the students to increase their understanding about plant concept and motivate them to interest to study science.
\end{abstract}

Keywords: Interactive teaching, constructivist, concept

\section{A. Pendahuluan}

Proses pembelajaran sains yang tepat, harus memberikan kesempatan bagi siswa untuk dapat menguasai dan memiliki konsep, meningkatkan ketrampilan serta kemampuan berpikir berdasarkan situasi dan kondisi, sehingga siswa dapat membuat keputusan dan pemecahan masalah secara rasional dan kritis. Hal tersebut menuntut guru untuk mampu membimbing siswa, agar dapat menemukan dan memiliki konsep dalam pemecahan masalah sehari-hari.

Berdasarkan hasil observasi yang telah dilakukan di Madrasah Ibtidaiyah swasta yang berada di Kodya Malang, didapatkan bahwa prestasi belajar siswa MI khususnya prestasi belajar sains adalah rendah. Dari hasil pengamatan didapatkan bahwa proses pembelajaran sainsmasih bersifat "transfer pengetahuan", sehingga tidak sesuai dengan tuntutan kurikulum dan kebutuhan siswa. Dengan kata lain pembelajaran masih berpusat pada guru dengan banyak mengandalkan metode ceramah dan 
melatih siswa untuk menjawab pertanyaan-pertanyaan yang ada dalam buku paket serta buku kumpulan soal.

Bahkan demonstrasi yang dilakukan oleh guru tidak dipersiapkan dengan baik, sehingga siswa kurang berpartisipasi aktif, baik secara fisik maupun mental. Guru kurang memperkenalkan lingkungan sebagai sarana belajar, a kibatnya siswa kurang termotivasi dan tidak tertarik untuk belajar sains. Hal ini dapat dilihat pada pertanyaan yang diajukan oleh guru kurang mampu memotivasi siswa untuk mengembangkan keterampilan berfikirnya, karena hanya menuntut kemampuan menghafal konsep. Sementara selama kegiatan pembelajaran, siswa tidak pernah mengajukan pertanyaan. Target yang ingin dicapai oleh sekolah adalah agar siswa dapat mencapai nilai yang tinggi saat tes prestasi belajar, karena mempertimbangkan tuntutan masyarakat. Proses pembelajaran dan target demikian tidak sesuai dengan tujuan pembelajaran sains seperti tercantum dalam kurikulum sains di madrasah ibtidaiyah.

Salah satu model pembelajaran yang mengacu pada pendekatan pembelajaran konstruktivis adalah model pembelajaran interaktif, yang menekankan pada aspek pertanyaan siswa sebagai ciri utamanya. Peter Fensham (1994:151) mengemukakan bahwa pendekatan konstruktivis banyak dijadikan dasar pengembangan model pembelajaran sains karena dianggap sesuai dengan karakteristik pembelajaran sains, yang memperhatikan dan mempertimbangkan pengetahuan awal siswa yang mungkin diperoleh siswa dari lingkungan di luar sekolah.

Bahan kajian tumbuhan merupakan materi yang dapat menimbulkan ketertarikan siswa pada kehidupan. Siswa dapat mengembangkan keingintahuannya tentang tumbuhan, dengan saling berinteraksi dengan sesama anak, dengan caranya sendiri dan juga dengan lingkungannya. Anak-anak mengenal alam melalui tumbuhan yang hidup di lingkungan sekitar mereka. Tumbuhan memberikan kehidupan pada mahluk hidup di bumi, dengan menyediakan makanan dan gas oksigen. Anak-anak mendapatkan banyak hal yang mengejutkan dan menarikpada pembelajaran tumbuhan.

Berdasarkan uraian tersebut maka guru harus memiliki pertimbangan ketika akan melakukan pembelajaran tumbuhan, baik pertimbangan dari segi siswa, yang meliputi teori perkembangan peserta didik dan teori belajar, juga pertimbangan dari tehnik penyampaian materi pembelajaran.

Salah satu pertimbangan penting bagi guru, dalam proses pembelajaran siswa MI, adalah menyadari bahwa siswa MI memiliki pengetahuan awal yang diperoleh melalui interaksi dengan lingkungan, keinginan mengungkapkan apa yang telah diketahui, dan rasa penasaran yang tinggi, untuk menggali dan mengetahui sendiri hal-hal baru. Maka 
diharapkan guru dapat menggali apa yang diketahui siswa, sebagai pemahaman awal tentang materi yang akan dipelajarinya, dan memberikan kesempatan bagi siswa untuk menggali dan mengkonstruk pengetahuan. Guru dituntut agar dapat mengarahkan dan membimbing siswa, untuk mengaplikasikan konsep yang telah dimiliki dalam kehidupan sehari-hari.

Untuk mengantisipasi kesalahan konsep yang mungkin terjadi pada siswa, maka guru perlu mengupayakan model pembelajaran yang dapat membantu siswa menguasai sekaligus mampu mengembangkan konsepkonsep tentang tumbuhan di dalam kehidupan sehari-hari, dengan memperhatikan pengetahuan awal siswa tentang hal tersebut. Suatu tantangan bagi guru untuk merencanakan sekaligus menerapkan dan mengembangkan proses pembelajaran pada topik tumbuhan .

\section{B. Penggunaan Model Pembelajaran Interaktif pada Materi Tumbuhan}

Sains didefinisikan sebagai cara mencari tahu tentang alam semesta secara sistematis untuk menguasai pengetahuan (Depdiknas, 2006:2). Penguasaan pengetahuan atau informasi baik berupa fakta, konsep dan prinsip dapat dilaksanakan dengan pembelajaran sains.

Pendidikan sains di MI, dipandang sebagai permulaan untuk menanamkan konsep dasar tentang pemahaman alam sekitar siswa. Sains bagi siswa MI lebih menekankan pada kecakapan proses (Suderadjat, 2004:75), karena kecakapan proses merupakan kecakapan prasyarat untuk menggali dan mengembangkan sains lebih lanjut. Kecakapan proses terdiri dari kecakapan proses dasar dan kecakapan proses kompleks, bagi siswa MI kecakapan proses dasar meliputi kecakapan untuk mengamati, kecakapan untuk mengelompokkan, kecakapan untuk melakukan pengukuran, dan kecakapan untuk mengkomunikasikan .

Anak usia MI berada pada tahap operasional konkrit, karena itu proses belajar mengajar perlu dihubungkan dengan kejadian sehari-hari yang akrab dengan siswa (Syamsu Yusuf,2007:137). Hal ini dilakukan dengan cara memberikan pengalaman langsung kepada siswa atau cara lain yang dapat memberikan efek pengkongkritan fakta atau fenomena. Selain itu dengan penyajian obyek nyata diharapkan dapat mendorong siswa merefleksikan hasil kegiatan tersebut dalam kehidupan sehari-hari, sehingga muncul sikap peduli terhadap berbagai peristiwa di sekelilingnya dan tumbuh sikap ilmiah serta kreatif.

Siswa MI menampakkan kesenangan belajar dan ingin mempelajari banyak hal. Rasa ingin tahu tersebut sangat tinggi terlihat dari keinginan untuk mengeksplorasi lingkungan. Anak-anak senang bermain di parit, sungai, sawah, memanjat pohon, mencari belut, ikan atau hewan-hewan kecil lainnya, berenang di sungai atau kolam, mencoba berbagai permainan, dan mencoba segala sesuatu yang dilihat. Oleh karena itu guru 
diharapkan dapat memberikan kesempatan kepada anak untuk dapat mengeksplorasi lingkungannya dalam membelajarkan siswa. Dengan menciptakan situasi belajar yang menyenangkan, maka siswa merasa senang belajar dan memiliki keyakinan diri, kesenangan dan keyakinan diri ini penting untuk mengembangkan keterammpilan intelektual, emosional, dan sosial, setaraf dengan tingkat perkembangannya (Prayitno, 1992).

Dengan demikian hendaknya guru memberikan kesempatan dan rangsangan agar siswa dapat mengembangkan berbagai ketermpilan. Materi belajar hendaknya terkait dengan pengalaman siswa yang ada di lingkungannya dengan menyajikan gambar, contoh langsung, dan pengalaman langsung dari situasi asli.

\section{Pendekatan Konstruktivisme}

Yuliariatiningsih(2003:3) mengemukakan bahwa pendekatan kontruktivisme adalah salah satu pandangan tentang proses pembelajaran yang menyatakan bahwa proses belajar diawali dengan terjadinya konflik kognitif. Konflik tersebut diatasi melalui pengala man dan pengetahuan diri pada proses pembelajaran. Sehingga pengetahua dibangun sendiri oleh siswa.

Pendekatan konstruktivisme merupakan salah satu strategi pembelajaran yang berpusat pada siswa. Peran guru bukan memberikan dan mentransfer pengetahuan, tetapi membangkitkan kemampuan berpikir siswa dalam belajar. Guru sebagai promotor pembelajaran, yang mempromosikan fasilitas belajar, agar siswa terbiasa belajar dan berlatih sendiri untuk mencapai tujuan tertentu.

Konstruktivisme menganggap bahwa pengetahuan dihasilkan melalui proses konstruksi manusia, yang diperoleh dari interaksi dengan obyek, fenomena, pengalaman dan lingkungan (Peter Fensham,1994:147). Proses belajar mengajar menurut konstruktivisme adalah upaya guru untuk membangkitkan kemampuan berpikir siswa, setelah memperoleh pengetahuan dari lingkungan. Sagala (2005:188) menyarankan beberapa prinsip mengajar sains, yaitu

a. Mengakui adanya konsepsional yang dimiliki siswa melalui pengalaman sebelumnnya.

b. Menekankan pada kemampuan minds-on dan hands-on.

c. Mengakui bahwa dalam proses pembelajaran terjadi perubahan konseptual.

d. Mengakui bahwa pengetahuan tidak dapat diperoleh secara pasif.

e. Mengutamakan terjadinya interaksi sosial 
Pendekatan kontruktivisme dapat dilakukan dengan menggunakan metode penelitian terbimbing terhadap berbagai media pembelajaran, antara lain melalui model, gambar, alat peraga dan alat bantu lainnya. Hal tersebut dapat mendorong siswa aktif melakukan proses penguasaan konsep dan membentuk pengetahuan baru.

Pembelajaran konstruktivisme meliputi empat tahap yaitu:

\section{Apresiasi}

Guru memotivasi siswa dengan memberikan pertanyaan tentang materi yang akan dibahas, untuk mengukur pengetahuan awal siswa tentang materi tersebut. Sehingga guru mengetahui darimana memulai pembelajaran. Melalui apresiasi juga, guru dapat menghubungkan antara konsep awal siswa dengan materi yang akan dibahas.

\section{Eksplorasi}

Pada tahap ini, siswa memiliki kesempatan untuk menyelidiki, menggali dan menemukan konsep. Guru dapat menyajikan berbagai kegiatan pecobaan, penelitian atau membuat pertanyaa-pertanyaan, baik pertanyaan langsung, maupun dalam bentuk lembar kegiatan siswa (LKS), yang bertujuan untuk menggali potensi kemampuan berpikir siswa.

\section{Diskusi dan penjelasan konsep}

Setelah siswa melakukan percobaan, pengamatan atau menjawab pertanyaan-partanyaan, siswa diminta untuk menjelaskan hasilnya, dan didiskusikan dengan temannya, pada tahap ini guru membimbing kegiatan siswa, dengan memberikan pengarahan, penguatan dan penjelasan tentang materi yang sedang dipelajari, tetapi siswa sendiri yang membuat kesimpulan dan membentuk pemahamannya.

\section{Pengembangan dan Aplikasi}

Setelah siswa membuat kesimpulan dan membentuk pengetahuan, guru berusaha agar konsep yang telah dibangun siswa dapat diaplikasikan pada permasalahan yang dimunculkan. Guru dituntut untuk mampu menyajikan suatu kegiatan atau memunculkan suatu permasalahan baru, yang ada hubungannya dengan materi yang telah dipelajari siswa dengan kehidupan sehari-hari.

\section{Model Pembelajaran Interaktif}

Model pembelajaran interaktif adalah suatu pendekatan yang merujuk pada pandangan konstruktivisme yang menitikberatkan pada pertanyaan siswa, memberi kesempatan pada siswa untuk mengajukan pertanyaan untuk kemudian melakukan penyelidikan yang berkaitan dengan pertanyaan yang mereka ajukan (Nuryani, 2005:97). Pertanyaan yang diajukan siswa dapat sangat bervariasi sehingga guru perlu 
melakukan langkah-langkah mengumpulkan, memilih, dan mengubah pertanyaan tersebut menjadi suatu kegiatan yang spesifik.

Langkah-langkah pembelajaran sains dengan menggunakan model pembelajaran interaktif adalah tampak pada bagan 1 berikut ini:

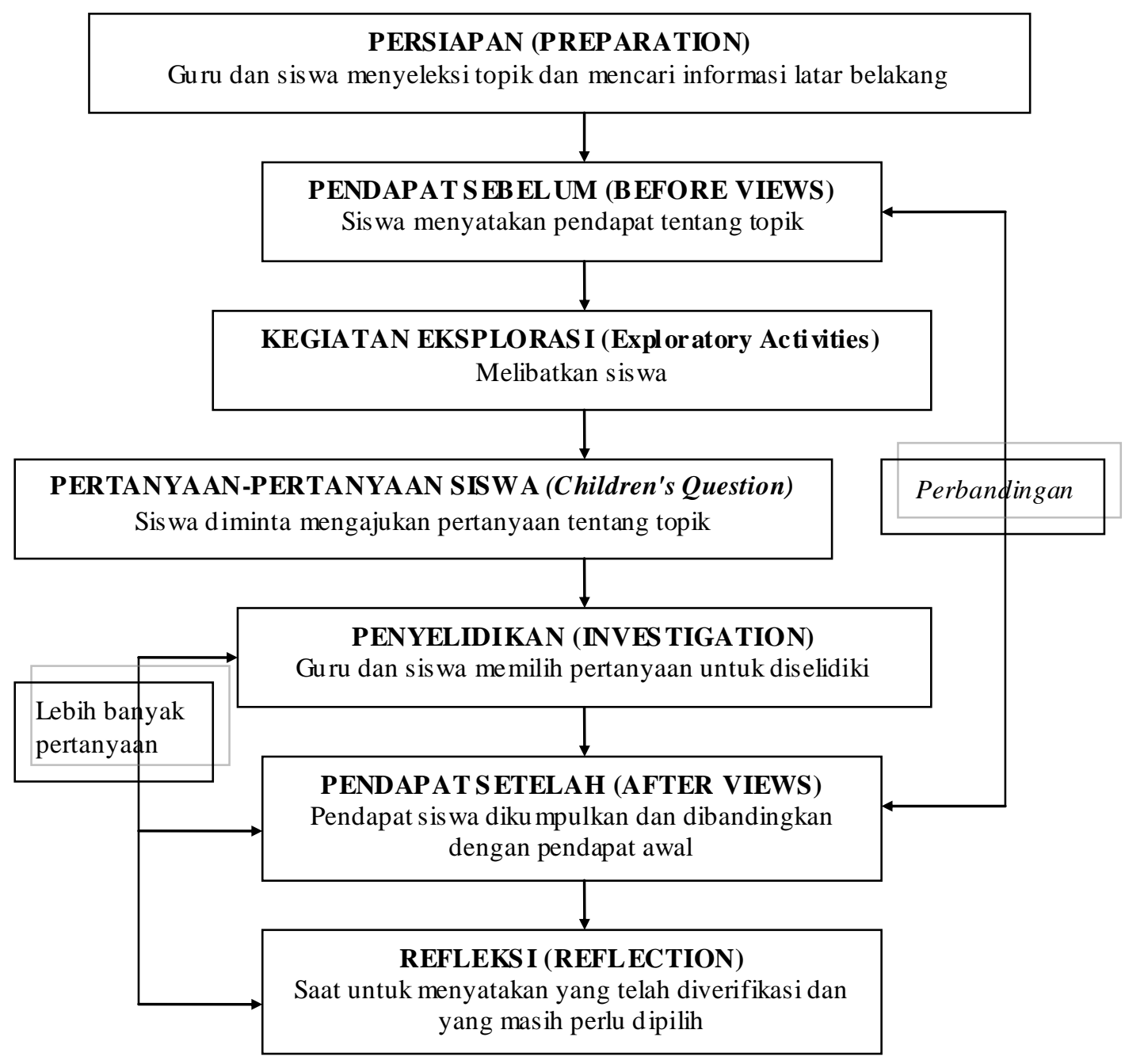

Bagan1. Urutan Pembelajaran Menggunakan Model Pembelajaran

\section{Interaktif}

(Dari Faire \& Cosgrove dalam Harlen,W.,1996)

Langkah-langkah yang harus diikuti dalam model pembelajaran interaktif untuk bahan kajian tumbuhan adalah sebagai berikut:

1. Persiapan 
Guru dan siswa memilih topik dan mencari latar belakang, misalkan: apakah tumbuhan juga minum setiap hari?

\section{Pendapat Sebelum (Before Views)}

Guru bertanya mengenai hal-hal yang sudah diketahui siswa mengenai topik. Gagasan yang muncul saat ini dibandingkan dengan pendapat setelah (after views) yang dikumpulkan setelah penyelidikan. Pernyataan pada "pendapat sebelum" dapat menjadi sumber untuk penyelidikan. Mungkin ada siswa yang menyatakan bahwa tumbuhan mempunyai mulut, tumbuhan akan mati bila tidak diberi pupuk, tumbuhan bergerak seperti manusia, tumbuhan dapat menjadi tua, tumbuhan dapat tinggi.

\section{Kegiatan Eksplorasi (Eksploratory Activities)}

Dimaksudkan untuk merangsang berpikir dan merangsang siswa mengajukan pertanyaan. Dalam tahap ini dilakukan diskusi kecil antar siswa serta antara siswa dengan guru. Semua pertanyaan dicatat di papan tulis. Pertanyaan yang mungkin muncul: dari manakah tumbuhan mendapatkan makanan?, apa makanan tumbuhan?, apakah semua daun berwarna hijau?, a pakah bentuk daun selalu sama?.

\section{Pertanyaan Siswa (Children's Questions)}

Pada tahap ini guru mengumpulkan pertanyaan tambahan selain yang ditulis di papan tulis, misalnya pertanyaan-pertanyaan yang bernada hipotesis ,apakah tumbuhan yang semakin tua jumlah daunnya semakin banyak?

\section{Penyelidikan (Investigation)}

Pertanyaan yang terkumpul diseleksi, didasarkan pada kemungkinan untuk diselidiki/ diteliti. Penyeleksian dapat dilakukan bersama (sekelas) atau tiap kelompok memilih pertanyaan yang akan diteliti. Guru membantu dalam merencanakan penyelidikan, mengumpulakn sumber, melakukan pengamatan dan mempersiapkan charta untuk melaporkan hasil. Misalkan yang dipilih adalah penyelidikan tentang apakah makanan tumbuhan?

\section{Pendapat Setelah (After Views)}

Pendapat siswa dikumpulkan dan dibandingkan dengan pendapat awal. Jika dalam penyelidikan tersebut ditemukan bahwa tumbuhan juga memerlukan makanan, guru perlu memberi penekanan untuk menghindari miskonsepsi yang muncul sebelum penyelidikan

7. Refleksi (Reflection) 
Langkah ini penting karena siswa dirangsang untuk urun pendapat mempertimbangkan secara kritis apa yang telah dilakukan dan mengetahui apa yang belum ditemukan serta apa yang sudah.

\section{Model pembelajaran interaktif pada materi tumbuhan}

Pembelajaran tumbuhan dengan menggunakan model pembelajaran interaktif adalah tepat untuk meningkatkan pemahaman konsep siswa tentang tumbuhan karena anak usia kelas III MI pada umumnya berada pada rentang usia 8-13 tahun yang menurut Piaget merupakan tahap operasional konkrit. Tahap tersebut adalah tahap ke3 dari tahapan perkembangan intelektual. Tahap ini merupakan tahap permulaan berpikir rasional. Pada tahap operasional konkrit ini anak akan mampu berpikir logis melalui obyek-obyek konkrit dan sulit memahami hal-hal yang hanya dipresentasikan secara verbal. Peristiwa berfikir dan belajar anak pada tahap ini sebagian besar melalui pengalaman yang nyata yang berawal dari proses interaksi anak dengan obyek (benda) bukan dengan lambang, gagasan, ataupun abstraksi, seperti mempelajari gravitasi (Edi Hendri,2004:31).

Berdasarkan karakteristik perkembangan intelektual tersebut maka dalam pembelajaran konsep tumbuhan untuk siswa MI harus dimulai dari hal-hal yang nyata (konkrit) ke abstrak, dari mudah ke sukar, dari sederhana ke rumit, dan dari dekat ke jauh. Dengan kata lain pembelajaran konsep tumbuhan dimulai dari apa yang ada pada/sekitar siswa dan yang dikenal, diminati serta diperlukan siswa.

Hal tersebut dapat dilihat pada pembelajaran materi tumbuhan dengan model pembelajaran interaktif. Dalam model pembelajaran tersebut siswa diajak untuk melihat secara nyata (konkrit) dari obyek tumbuhan/tanaman yang telah dibawa siswa dari rumah ataupun telah disediakan oleh guru. Kemudian siswa mengamati atau mengobservasi dari dekat tanaman yang dibawa atau yang disediakan guru. Dengan proses pengamatan pada obyek nyata atau konkrit yang berupa tanaman tersebut dapat melatih ketrampilan berfikir dan ketrampilan proses sains siswa dalam memecahkan suatu persoalan melalui aktivitas hands-on, misalnya kegiatan-kegiatan ketrampilan psikomotorik dalam melakukan observasi dalam hal ini adalah kemampuan siswa untuk mengamati tumbuhan yang telah dibawanya, kemampuan melakukan pencatatan hasil pengamatan yang meliputi warna daun, bagian-bagian tumbuhan, warna batang dsb.

Untuk ketrampilan berfikir dapat dicapai juga melalui aktivitas minds-on yaitu aktivitas yang berhubungan dengan ketrampilan intelektual seperti ketrampilan dalam mengajukan pertanyaan tentang dari manakah tumbuhan mendapatkan makanan?, apakah makanan tumbuhan?, apakah semua daun berwarna hijau, juga ketrampilan 
menjawab pertanyaan tentang tumbuhan mendapatkan makanan dari tanah tempat tumbuhnya, makanan tumbuhan adalah air, mineral dan pupuk, serta kebanyakan daun berwarna hijau. Penggunaan model pembelajaran interaktif pada bahan kajian tumbuhan dapat juga memberi suasana bermain bagi siswa melalui aktivitas eksplorasi dan penyelidikan, serta melatih siswa untuk mengungkapkan rasa ingin tahunya pada tahap pertanyaan siswa.

Selain berdasarkan psikologi perkembangan intelektual Piaget, pembelajaran konsep tumbuhan dengan model pembelajaran interaktif juga menurut teori belajar konstruktivisme. Teori tersebut memandang pengetahuan (terutama pengetahuan logiko-matematik dan pengetahuan sosial dibangun sendiri oleh anak melalui pengalaman dimana terjadi interaksi antara struktur kognisi (pengetahuan) awal yang telah dimilikinya dengan informasi dari lingkungan. Interaksi seperti ini menurut teori belajar konstruktivisme disebut sebagai perubahan konseptual (Bell,1993:24) .Menurut faham konstruktivis belajar adalah proses yang aktif dan berkesinambungan yang dilakukan siswa dalam menggunakan informasi dari lingkungan untuk membangun sendiri pemahamannya. Proses ini dilakukan siswa dengan beranjak dari pengetahuan dan pengalaman awal mereka (Shepardson\&Moje,1994:490). Dengan merujuk pada karakteristik pembelajaran konstruktivisme, maka pembelajaran tentang tumbuhan dengan model pembelajaran interaktif dapat dilihat dari beberapa hal berikut:

Pertama, pada pembelajaran tersebut mempertimbangkan bahwa pengetahuan awal siswa sangat berperan dalam pengalaman belajar mereka (Horsley, et al.,1994:47). Pengetahuan awal (prakonsepsi) dapat terdiri dari miskonsepsi (berbeda dengan konsepsi yang sekarang diterima para ilmuwan) dan konsep-konsep intuitif yang dibenarkan secara ilmiah.Untuk mengetahui miskonsepsi siswa dengan melakukan pertanyaan apersepsi, juga kegiatan eksplorasi pada awal pembelajaran. Kemungkinan miskonsepsi yang muncul adalah mengapa tumbuhan tidak bergerak?, mengapa tumbuhan tidak mempunyai mulut?, apakah tumbuhan akan mati bila tidak diberi pupuk?, apakah tumbuhan minum setiap hari?, apakah semua tumbuhan menguntungkan manusia?, dan sebagainya.

Kedua, dalam model pembelajaran interaktif pada konsep tumbuhan terjadi proses transformasi konsepsi yang menyebabkan terjadinya perubahan konseptual pada diri siswa. Proses ini ditandai dengan adanya bimbingan guru maka dengan ktivitas siswa sendiri mengalami transformasi (perubahan dan peningkatan) konsep.Yang dimaksudkan adalah perubahan dari miskonsepsi menjadi konsepsi yang benar, meningkat dari penguasaan konsep pada tahap tertentu ke 
tahap yang lebih tinggi. Misalnya: terjadinya perubahan dari miskonsepsi tentang mengapa tumbuhan tidak mempunyai mulut menjadi konsep yang benar bahwa tumbuhan tidak seperti manusia yang harus mempunyai mulut. Tumbuhan makan melalui akar tumbuhan.

Ketiga, dalam pembelajaran tersebut terjadi perubahan konseptual atau pengetahuan dikonstruksi siswa melalui partisipasi aktif dalam aktivitas hands-on dan minds-on seperti telah diuraikan sebelumnya. Dapat dikatakan siswa sendiri yang aktif mengkonstruksi pengetahuannya, tidak dari guru karena guru hanya sebagai fasilitator untuk mengaktifkan pengetahuan yang telah dimiliki siswa sebelumnya tentang tumbuhan.

Horsley (1994:47) menegaskan tepatnya model pembelajaran yang didasarkan pada konstruktivisme untuk pembelajaran sains di tingkat sekolah dasar. Alasannya adalah bahwa dalam model pembelajaran ini siswa diberi kesempatan untuk mengemukakan pendapatnya dengan kata-katanya sendiri, menguji ide-idenya sendiri berdasarkan pengetahuan yang dimiliki sebelumnya, serta berpeluang untuk membentuk kepekaan terhdap lingkungan.

Pembelajaran sains pada bahan kajian tumbuhan dengan model pembelajaran interaktif akan efektif dalam meningkatkan kemampuan berfikir siswa kelas III Madrasah Ibtidaiyah bila dalam pembelajaran tersebut terjadi proses kadar on-task (aktivitas edukatif) yang tinggi dan rendahnya kadar off-task (aktivitas non-edukatif) siswa.

Hal sebaliknya akan terjadi bahwa model pembelajaran interaktif pada bahan kajian tumbuhan menjadi tidak efektif dan bahkan tidak dapat untuk meningkatkan kemampuan berfikir siswa kelas III Madrasah Ibtidaiyah jika dalam pembelajarannya terjadi:

1) Siswa kurang aktif dalam mengajukan pertanyaan-pertanyaan setelah melakukan eksplorasi,

2) Obyek-obyek yang akan dipelajari pada tahap eksplorasi dan penyelidikan tidak dipersiapkan dengan baik

3) Siswa tidak terampil dalam bahasa lisan, sehingga pembelajaran tidak berjalan seperti yang diharapkan

4) Siswa tidak dapat mengungkapkan pertanyaan

\section{Kesimpulan}

Berdasarkan uraian diatas, maka dapat disimpulkan bahwa dalam membantu siswa untuk meningkatkan motivasi, pemahaman dan mengembangkan konsep tentang tumbuhan pada siswa MI dapat dilakukan melalui penggunaan model pembelajaran interaktif . 


\section{Daftar Pustaka}

Bell B. 1993. Children's Science, Constructivisme and Learning in Science. Victoria: Deakin University Press.

Departemen Pendidikan dan Kebudayaan. 2006. Kurikulum Tingkat Satuan Pelajaran SD/MI. Jakarta: Depdiknas Republik Indonesia.

Eddy M. H. (1996). "Pendidikan dan Pembelajaran Sains Yang Bagaimana Yang Cocok dan Berguna Untuk Siswa-Siswa Sekolah di Indonesia". Majalah Pendidikan Ilmu Pengetahuan Alam: Khazanah Pengajaran IPA,1,(2),

20-22. Bandung: PPS IKIP Bandung.

Fensham Peter. 2004. The Content of Science.Washington.D.C: The Falmer Press

Harlen, W. (1996). Teaching and Learning Primary Science. London: Paul Chapman Publishing Ltd.

Rustaman Nuryani.2004. Strategi Belajar Mengajar. Bandung: Universitas Pendididkan Indonesia.

Sagala. (2005). Konsep dan Makna Pembelajaran. Bandung: Alfabeta.

Shepardson, D.P. et al .1994. "The impact of science demonstration on children's understanding of air pressure". Journal of Research in Science Teaching, 31(3),243-258.

Suderajat. 2004. Implementasi Kurikulum Berbasis Kompetensi. Bandung: CV. Cipta Karya Grapi.

Yuliariatiningsih.M . 2004. Implementasi Kurikulum Berbasis Kompetensi : Model-model Pembelajaran. Bandung; CV.Bina Media Informasi.

Yusuf Samsu .2007. Pedagogik Pendidikan Dasar. Bandung: Sekolah PascaSarjana Universitas Pendidikan Indonesia 